\title{
Haematophagy and Cleptohaematophagy of Clerada apicicornis (Hemiptera: Lygaeidae), a Potential Biological Control Agent of Rhodnius prolixus (Hemiptera: Reduviidae)
}

\author{
Mariela Torres $^{+}$, Estrella Cárdenas, Sandra Pérez, Alberto Morales \\ Laboratorio de Entomologia, Instituto Nacional de Salud, Avenida Eldorado, Carrera 50 Zona 6, Apartado Aereo \\ 80080, Santafé de Bogotá, Colombia
}

Because of its ability to prey on Triatominae in rural houses, Clerada apicicornis has been suggested as a potential biological control agent of Rhodnius prolixus. It has also been suggested as a potential vector of mammalian trypanosomes such as Trypanosoma cruzi, because of its ability to take blood directly from mammals. To help resolve these conflicting ideas, we assessed the haematophagic behaviour of $\mathrm{C}$. apicicornis by carrying out feeding trials on laboratory animals. Cleptohaematophagic behaviour was also assessed by allowing $\mathrm{C}$. apicicornis to feed on $\mathrm{R}$. prolixus previously engorged with avian blood. The low proportion of blood meals taken directly from laboratory animals indicates a facultative haematophagy in this species, whereas a greater proportion of nymphs and adults were able to obtain vertebrate blood by predation on engorged $\mathrm{R}$. prolixus. The results suggest that $\mathrm{C}$. apicicornis is unlikely to be effective as a biological control agent, but is also unlikely to have a significant role in the transmission of vertebrate pathogens.

Key words: Clerada apicicornis - Rhodnius prolixus - biological control - cleptohaematophagy

Clerada apicicornis Signoret, 1863, is the most widespread of the Cleradini (Hemiptera, Lygaeidae, Rhyparochrominae) recorded from tropical areas of all zoogeographical zones (Malapatil 1981, 1983). Although the great majority of Lygaeidae are phytophagous, feeding on mature seeds or sap, there are many predatory species, and several of the Cleradini are also believed to be at least facultative blood-suckers (Wilton-Smith 1978, Schuh $\&$ Slater 1995). In general, the 50 recognized species of Cleradini are confined to the Old World tropics, except for the introduction of C. apicicornis into the Western hemisphere. C. apicicornis has been assumed to be haematophagous from examination of its mouthparts (Sweet 1960, Harrington 1988), from records of its occurrence in rodent and bird nests (Sweet 1967) and from biochemical determination of vertebrate blood in the intestine of dried specimens (Harrington 1990). At one time, the haematophagous habits of C. apicicornis in Latin America, and its occasional occurrence in

\footnotetext{
This research was supported by Colciencias, Basic Sciences Program, and by Instituto Nacional de Salud, Colombia.

Corresponding author. Fax: +571-3157341. E-mail: mtorres@ hemagogus.ins.gov.co

Received 15 April 1999

Accepted 13 October 1999
}

rural dwellings, led to the suggestion that it could act as a vector of Trypanosoma cruzi, causative agent of Chagas disease. These suggestions (eg. Castro-Ferreira \& Deane 1938a,b) were refuted by a detailed review of the evidence then available (Lent 1939) but have been raised again by Harrington (1990). In contrast, several authors have suggested that $C$. apicicornis could find use as a predator and biological control agent of Triatominae, the widespread reduviid vectors of T. cruzi (eg. Simmonds 1971). This paper presents experimental studies of the feeding of $C$. apicicornis on vertebrates and on Triatominae, as an attempt to clarify its potential role in the ecology of T. cruzi transmission.

\section{MATERIALS AND METHODS}

Adults and nymphs of $C$. apicicornis were collected from three of 55 rural houses in the village of Munanta, Department of Boyacá, Colombia (Torres et al. unpublished). They were used to establish a laboratory colony B feeding on cockroach, Blaberus atropus B at the Instituto Nacional de Salud in Bogota.

For studies of feeding on vertebrates, groups of 80 nymphs of each of the five instars were starved for three or six days, and then separated into four groups of 20 nymphs. Each group was then placed into a flask or muslin cage placed on the anaesthetised rabbit, mouse, hamster or turkey host for $1 \mathrm{~h}$. For studies of feeding on Triatominae, groups up to 25 nymphs or adults of $C$. apicicornis 
were placed with three to eight nymphs or adults of Rhodnius prolixus (Hemiptera: Reduviidae, Triatominae) previously fed on a turkey host. A control group of 25 nymphs was allowed to feed on Blaberus atropus following normal colony procedures. To check for blood ingestion, each of the $C$. apicicornis was subsequently triturated for analysis of blood content using the standard clinical procedure for analysis of blood in human faeces.

\section{RESULTS}

The blood analysis of $C$. apicicornis fed on $B$. atropus was negative in each case. For those offered a feed directly on vertebrates, the proportion subsequently with a detectable blood meal was low amongst all nymphal stages (0-14\%) but generally much higher in adults (up to 77\%) (Table I). All host species were fed upon by at least some of the insects and in all cases the longer period of starvation prior to feeding seems to have increased the proportion that fed.

For insects offered $R$. prolixus as prey, the proportion of ingested blood seemed size dependent. The tiny first instar nymphs of $C$. apicicornis generally bit only the legs and antennae of the prey, rarely the abdomen, and none subsequently had detectable vertebrate blood meals. Second instars bit the prey abdomen more readily and a proportion $(20 \%)$ subsequently had detectable blood meals. Third, fourth and fifth instar nymphs, and adults, generally bit and adhered firmly to the prey abdomen, with up to $100 \%$ subsequently having vertebrate blood meals (Table II). During the process, the prey insects could be seen to shake the body, run forwards and rub the abdomen with the legs, in apparent attempts to dislodge the predators. In all cases however, were the Rhodnius killed by the predatory feeding of Clerada.

\section{DISCUSSION}

C. apicicornis has frequently been encountered in rural dwellings in the tropical valleys of Colombia (Morales et al. 1969, Torres et al. unpublished) and has been proposed both as a potential vector of $T$. cruzi, and as a potential control agent by preying on the more common triatomine vectors such as $R$. prolixus. Our studies suggest that it is unlikely to have an important role in either capacity. Although a small proportion of the insects can take blood directly from a range of vertebrate hosts, it is clear that the preferred feeding is by predation on other insects, so that the finding of vertebrate blood in the gut contents of museum specimens of C. apicicornis (Harrington 1990) seems most likely to have resulted from feeding on haematophagous insects rather than from feeding directly on vertebrate hosts. Similar cleptohematophagy has been frequently reported for other hemipteran predators such as Emesinae (Hemiptera, Reduviidae) acquiring vertebrate blood by feeding on engorged mosquitoes (White et al. 1972) and may represent an important phase in the evolutionary transition from predator to blood-sucker, as suggested by Schofield and Dolling (1993).

TABLE I

Percentage of Clerada apicicornis taking bloodmeals from different vertebrate hosts

\begin{tabular}{|c|c|c|c|c|c|c|c|}
\hline Stage & $\begin{array}{l}\text { Fasting } \\
\text { time }\end{array}$ & Mouse & Hamster & Rabbit & Turkey & $\begin{array}{c}\text { Prom }^{a} \\
\text { time }\end{array}$ & $\begin{array}{c}\text { Prom }^{b} \\
\text { stage }\end{array}$ \\
\hline $1 \mathrm{st}$ & $\begin{array}{l}3 \\
6\end{array}$ & $\begin{array}{l}3.33 \\
3.33\end{array}$ & $\begin{array}{r}0.0 \\
10.0\end{array}$ & $\begin{array}{l}8.33 \\
6.67\end{array}$ & $\begin{array}{l}0.0 \\
0.0\end{array}$ & $\begin{array}{l}3.75 \\
6.67\end{array}$ & 5.2 \\
\hline 2nd & $\begin{array}{l}3 \\
6\end{array}$ & $\begin{array}{l}1.67 \\
1.67\end{array}$ & $\begin{array}{l}0.0 \\
6.67\end{array}$ & $\begin{array}{l}1.67 \\
8.33\end{array}$ & $\begin{array}{l}0.0 \\
0.0\end{array}$ & $\begin{array}{l}0.84 \\
5.56\end{array}$ & 3.2 \\
\hline $3 r d$ & $\begin{array}{l}3 \\
6\end{array}$ & $\begin{array}{l}5.00 \\
3.33\end{array}$ & $\begin{array}{c}0.0 \\
14.00\end{array}$ & $\begin{array}{r}0.0 \\
1.67\end{array}$ & $\begin{array}{l}0.0 \\
0.0\end{array}$ & $\begin{array}{l}1.67 \\
6.48\end{array}$ & 4.1 \\
\hline 4 th & $\begin{array}{l}3 \\
6\end{array}$ & $\begin{array}{l}4.92 \\
5.00\end{array}$ & $\begin{array}{l}0.0 \\
5.0\end{array}$ & $\begin{array}{l}0.0 \\
0.0\end{array}$ & $\begin{array}{l}0.0 \\
0.0\end{array}$ & $\begin{array}{l}1.25 \\
3.33\end{array}$ & 2.3 \\
\hline 5 th & $\begin{array}{l}3 \\
6\end{array}$ & $\begin{array}{l}1.67 \\
1.67\end{array}$ & $\begin{array}{l}5.0 \\
0.0\end{array}$ & $\begin{array}{l}0.0 \\
1.67\end{array}$ & $\begin{array}{l}5.0 \\
0.0\end{array}$ & $\begin{array}{l}2.92 \\
1.67\end{array}$ & 2.3 \\
\hline Adults & $\begin{array}{l}3 \\
6\end{array}$ & $\begin{array}{l}0.0 \\
3.33\end{array}$ & $\begin{array}{l}6.57 \\
14.0\end{array}$ & $\begin{array}{r}3.33 \\
13.33\end{array}$ & $\begin{array}{l}23.33 \\
77.19\end{array}$ & $\begin{array}{c}8.33 \\
27.0\end{array}$ & 17.7 \\
\hline $\begin{array}{l}\text { Prom } \\
\text { source }\end{array}$ & $\begin{array}{l}3 \\
6\end{array}$ & $\begin{array}{l}2.78 \\
3.05\end{array}$ & $\begin{array}{c}2.33 \\
10.0\end{array}$ & $\begin{array}{l}2.22 \\
5.28\end{array}$ & $\begin{array}{l}4.72 \\
13.5\end{array}$ & $\begin{array}{l}3.13 \\
8.0\end{array}$ & \\
\hline$\%$ Prom & & 2.92 & 6.17 & 3.75 & 9.2 & & \\
\hline
\end{tabular}

$a$ : average of blood meals taken in each fasting time; $b$ : average of blood meals taken per stage. 
TABLE II

Blood and haemolymph meals in Clerada apicicornis

\begin{tabular}{lcccccccc}
\hline Stage & 1st & 2nd & 3rd & 4th & 5 th & Male & Female & Total \\
\hline $\mathrm{n} / \mathrm{N}$ & $0 / 24$ & $4 / 20$ & $8 / 25$ & $8 / 8$ & $6 / 6$ & $6 / 7$ & $4 / 9$ & $36 / 99$ \\
$\%$ & 0 & 20 & 32 & 100 & 100 & 84 & 44 & 36 \\
\hline
\end{tabular}

\section{REFERENCES}

Castro-Ferreira L, Deane L 1938a. Encontro de um novo hematophago do homen com habitos domiciliares. Brasil Medico 52: 1137-1141.

Castro-Ferreira L, Deane L 1938b. Infeccão experimental do Clerada apicicornis Signoret 1863, pelo Shizotrypanum cruzi Chagas, 1909 (Nota Previa). Brasil Medico 52: 1181.

Harrington BJ 1988. Comments on the blood-feeding tribe Cleradini (Hemiptera: Lygaeidae: Rhyparochrominae) and description of a new genus and new species with legs modified for grasping. Ann Entomol Soc Am 8: 577-580.

Harrington BJ 1990. Detecting evidence of hematophagy in dry museum specimens of Clerada apicicornis (Hemiptera: Lygaeidae: Rhyparochrominae). Ann Entomol Soc Am 83: 545-548.

Lent H 1939. Sobre o hematofagismo da Clerada apicicornis e outros artropodos: sua importancia na transmissão da doenca de Chagas. Mem Inst Oswaldo Cruz 34: 583-606.

Malapatil MB 1981. Revision of Australian Cleradini (Heteroptera: Lygaeidae). Australian J Zool 29: 7738119.

Malapatil MB 1983. Revision of Australian Cleradini (Heteroptera: Lygaeidae) with a cladistic analysis of relationships with the tribe. Australian J Zool 31: 205-225.

Morales A, Corredor-Arjona A, Osorno-Mesa E, Parra-
Marquez J 1969. Infeccion natural de Mus musculus con Trypanosoma cruzi, en una region de Colombia, S.A. Rev Acad Colombiana de Ciencias Exactas Fisicas y Naturales 13: 375-377.

Schofield CJ, Dolling WR 1993. Bedbugs and kissingbugs (bloodsucking Hemiptera). In RP Lane \& RWCrosskey (eds), Medical Insects and Arachnids, Chapman \& Hall, London, UK, p. 483- 516.

Schuh RT \& Slater JA 1995. True Bugs of the World (Hemiptera: Heteroptera): Classification and Natural History, Cornell University Press, New York, 336 pp.

Simmonds F 1971. Report on investigations into natural enemies of Triatoma for the World Health Organization, Commonwealth Institute of Biological Control, Trinidad.

Sweet MH 1960. The seed bugs: a contribution to the feeding habits of the Lygaeidae (Hemiptera: Heteroptera). Ann Entomol Soc Am 53: 317-321.

Sweet MH 1967. The tribal classification of the Rhyparochrominae (Heteroptera: Lygaeidae). Ann Entomol Soc Am 60: 208-226.

Wilton-Smith PD 1978. Two hematophagous species of Clerada (Heteroptera: Lygaeidae) inhabiting the nest of the ringtail possum (Pseudocheirus peregrinus). $J$ Australian Entomol Soc 17: 1-4.

White GB, Boreham PFL, Dolling WR 1972. Synanthropic emesine bugs (Reduviidae, Emesinae) as predators of endophilic mosquitoes. Trans $R$ Soc Trop Med Hyg 66: 535-536. 